\title{
An assessment of the unsustainable Nigerian policies on palm oil
}

\author{
Sani Shehu* | Mohd Afandi Salleh | Yusuf Kamaluddin Ibrahim \\ Department of International Relations, Faculty of Law and International Relations, University Sultan \\ Zainul Abidin, Kuala Terengganu, Terengganu, Malaysia. \\ *Corresponding Author Email: sanishehu46@gmail.com
}

\begin{abstract}
The oil palm tree initially came from West African tropical forest. Oil palm fruit was firstly discovered before $14^{\text {th }}$ century, and Nigeria was among few areas of its discovery. Palm oil became one of the major global vegetable oils. Nigeria was the major global palm oil producer and exporter in 1960, but it failed in both production and export due to government failure to formulate good policies. However, the local consumption increases. The question here is that how these palm oil policies failed in Nigeria? This paper objective is to highlight unsustainable palm oil policies in Nigeria. It is qualitative research and used documents such as books, journals, newspapers and conference paper; it used open-ended interview to collect the data, and it employed inductive thematic analysis to analyse data from interview by using Atlas.ti software. This paper finding shows unsustainable palm oil policies in Nigeria which include plantations, innovations and settlements policies; 1950s to mid-1960s, military/civilian rule policies; 1967-1999, civil government policies; 1999. Nigeria needs to formulate and implement sustainable economic policies on palm oil to attract foreign investment. Moreover, Nigeria needs to emphasize on best global agricultural practices in line with Roundtable on Sustainable Palm Oil.
\end{abstract}

Article History

Received:

November 24, 2020

Revised:

June 5, 2021

Re-revised:

July 25,2021

Accepted:

August 1, 2021

Published:

September 19, 2021

Keywords: Nigeria, Nigerian policies, oil palm, palm oil, palm oil producer, palm oil policies, plantations, innovations, settlements, military rule, civilian rule, civil government.

How to Cite: Shehu, S., Salleh, M. A., \& Ibrahim, Y. K. (2021). An assessment of the unsustainable Nigerian policies on palm oil. Liberal Arts and Social Sciences International Journal (LASSIJ), 5(2), 79-87. https://doi.org/10.47264/idea.lassij/5.2.6

Publisher's Note: IDEA PUBLISHERS (IDEA Journals Group) stands neutral with regard to the jurisdictional claims in the published maps and the institutional affiliations.

Copyright: (C) 2021 The Author(s), published by IDEA PUBLISHERS (IDEA Journals Group).

Licensing: This is an Open Access article published under the Creative Commons AttributionNonCommercial 4.0 International License (http://creativecommons.org/licenses/by-nc/4.0/) 


\section{Introduction}

Oil palm is an African fruit. History of oil palm in Nigeria can be dated to hundred years ago. It is available in southern Nigeria as well as other parts of northern states. It is found mainly in coastline and riverine areas of south and north. These areas were good in oil palm production during the colonial era. After independence was achieved in 1960s, the present Cross River State was occupied with oil palm production, and now is the major oil palm plantations centre (White \& Oates, 1999). The emergence of the palm oil trade started when the Industrial Revolution was led by Britain, whereby palm oil has been applied for machine lubrication. Nigerian palm oil trade expanded in the 19th century after the abolition of slave trade. Palm oil is used to produce food and non-food products such as chocolate, margarine, soaps, candles, explosives and others. The main target of colonial government policy was to develop palm oil production, and this resulted to colonialism (Korieh, 2010). During the colonialism, the European palm oil demands for their markets, forced the farmers that owned small-scale production, to grow oil palm instead of basic food crops for the farmers daily life. This was rated as British indirect rule classical exploitation. It protected native people traditional practices on one hand, and on other hand, it imposed peasant-based production for export on them as well as taxing them simultaneously (Schoneveld, 2014).

Oil palm production in Nigeria started with two types of cultivations, which included wild grove and planted farms. The wild grove covered eighty percent of production, while the planted farms covered twenty percent of production only. This production faced many challenges ranging from long-time production of palm oil industry with outdated materials and techniques (PIND, 2011). In the early $20^{\text {th }}$ century, Nigeria became the major global producer and exporter of palm oil, and later it declined due to unsustainable policies on palm oil during the military rule in 1970s, up to the civilian government in 2006 (Anthony, 2014). This paper explores the unsustainable Nigerian policies on palm oil. The different governments adopted different policies on palm oil to improve this sector, but the policies failed due to the improper implementation.

\subsection{Oil Palm}

The oil palm came from the tropical forest of West Africa; it has been taken to Southeast Asian tropical forest. In Africa, the oil palm is used for food hundreds of years ago. Palm oil trade started during the British industrial revolution, whereby palm oil was applied to lubricate machines. In 1917, the oil palm tree was firstly implanted hundred years ago for commercial usage. Nevertheless, oil palm trees massive plantations started when there was advanced technology for extracting adequate palm oil (Green Palm, 2016). The oil palm tree requires certain conditions to grow such as heavy raining, warm temperature, and sunshine. The equator brings a frequent supply of sunshine and a warm climate. Harmoniously, in Southeast Asia, a sufficient quantity of raining is available especially in Malaysia and Indonesia, and tropical forest of West Africa especially Nigeria (Green Palm, 2016).

\subsection{Palm Oil}

Palm oil is a vegetable oil, which is very economic, profitable and more valuable than other vegetable oils. Per hectare of land, palm trees ranging from 145 to 160 are implanted. Palm kernel 0.5 tonnes and crude palm oil 3.9 is yielded by one hectare of oil palm tree each year. It is totalled up to palm oil products aggregate of 4.4 tonnes for each hectare in each year in terms of industrial average. In terms of comparative analysis, the rapeseed is one-hectare yields 1.33 
tonnes, sunflower one hectare yields 0.86 tonnes and soyabean one hectare yields 0.52 tonnes each year (Palm Oil Research, 2014). The global demand of palm oil for consumption in food has increased. The palm oil is applied in making of food stuffs, while palm kernel oil is applied in making of non-food stuffs as raw material, which includes cosmetics, toiletries and soaps (Malaysian-German Chamber of Commerce and Industry, 2017).

\section{Literature review}

The present Cross River before, it was the area with available land for plantation, but most of the oil palm areas were densely overpopulated. The formations of 36 oil palm plantations in 1952 to 1962 were located in Cross River state, and in 1955 became the estate of the Eastern Nigerian Development Corporation (Kilby, 1967). The ENDC and Eastern Regional Development Board (ERDB) supported the enhancing of oil palm industry, which comprised small farmers. This came at the time that; the board decided not to accept any low-quality oil from the farmers. The farmers were given seedlings, subsidy and fertilizer to improve palm grove. Later, this subsidy was given to them late, this caused problem to the farmers and the target was not achieved (Kilby, 1967). In 1976, the ENDC was dissolved, and the control of the estates was handed over to Cross River estates. In 1982, the activities of ENDC were shifted to the Agricultural Development Corporation, after it was dissolved. Later, the plantations were abandoned due to mismanagement. The government regained its control due to this mismanagement (Schoneveld, 2014). Unfortunately, in 1970s the agriculture declined to 26\% due to petroleum boom and government negligence of the sector. From 1974 to 1976, the palm kernels and palm oil trading died speedily (World Bank, 1978).

In Nigeria, the Structural Adjustment Program was forcibly implemented, which reduced the government participation in economic affairs. This programme encouraged partnership between public and private sectors. The oil palm estates were privatized to private individuals in order to make investment. While the privatization was very slow at the state level, and it was already begun in Cross River (Schoneveld, 2014). Nigerian governmental policy in collaboration with Vegetable Oil Development Programme (VODEP) was on agriculture. It was formulated to partner with private and public sectors to improve agriculture. The program faced challenges of inadequate funding, lack of frequent power supply, local and outdated processing machines, and the roads are very poor (Anyanwu et al., 2011). In 2010, the small holders utilized only $452 \mathrm{HA}$ from $4120 \mathrm{HA}$ of oil palm. The program failed due to corruption, mismanagement and lack of technical skills from the smallholders (Schoneveld, 2014). The study tries to bridge the gap and add to the body of knowledge, how the palm oil policies were unsustainable in Nigeria due to improper implementation of palm oil policies.

\section{Research methodology}

Research methodology is used in collecting data and analysing the data. Research is conducted generally to explain a particular phenomenon. According to Cress, research is generally conducted to develop appropriate and accurate assertions that can aid to explain the situation (Cress, 2012). This paper is a qualitative design applied to understand this research problem. Qualitative design is systematically used to explore a particular situation (Zhang \& Wildemuth, 2009). It used qualitative document analysis to clearly explain, analyse and conclude (WatsonManheim et al., 2002). This study used primary and secondary data. The secondary data were collected from documents such as journals, books, dissertations, articles, seminar papers, newspapers, and magazines. Primary data were collected from open-ended interview. The 
participants were interviewed in line of this paper objective. The interview was based on the telephone due to Covid-19 lockdown and movement control order. Three participants have been selected from Nigeria and asked to provide their different understandings based on this study. This paper is a purposive sampling, which is non-probability (Cress, 2012). This study applied inductive thematic analysis to analyse interview data. The data were analysed based on the participants' information and were critically interpreted by this research (Cohen et al., 2007). These data were analysed through editing, coding, and entry of the data. This research employed Atlas. ti software to analyse the interview data. Computer program like "Atlas.ti" supports qualitative analysis to organize, manage and code qualitative data efficiently (Zhang \& Wildemuth, 2009).

\section{Unsustainable Nigerian policies on Palm Oil: A discussion}

Federal and state governments adopted different palm oil policies to expand oil palm production in Nigeria. Most of these policies failed due to government lack of seriousness and dedication to implement the policies accordingly. The policies are as follows:

\subsection{Plantations, innovations and settlements policies; $1950 \mathrm{~s}$ to mid-1960s}

Nigerian economic development in 1952 was decentralized to the Eastern, Northern and Western regional administration. Eastern region recovered and adopted the colonial antiplantation tactics. It occurred during the period of rapid development of plantation in particular oil palm, rubber, and cocoa. All these came as a result of competition in expansion of oil palm plantation in Malaysia and Sumatra. It has been discovered that, good mills could extract 95\% of palm oil from the fruit, unlike $50 \%$ being extracted traditionally. The plantation used the good seeds that yielded more fruits than before (Udo, 1965). The innovation in agriculture started in 1960 after independence; this came up with agricultural revolution was said by first premier of eastern region, in person of Dr. Michael Okpara. In 1964, the five ENDC plantations were established to plant 47,000s ha (Kilby, 1967). In 1966, the same ENDC plantations to plant 60,000 ha (Schoneveld, 2014). Cross River state was the main centre, where the $80 \%$ of land for plantations existed. This attracted the European companies to establish oil palm plantation. Due to the low prices from marketing board, these companies relocated to other countries instead of investing in rubber (Udo, 1965).

The government vision was to fund agriculture, improve farming and form farm settlements as African socialism. The Igboland and Cross River were chosen to be the location of the farm settlements. The farm settlements were given more consideration due to oil palm plantation, and its mixture with food crops and rubber (Korieh, 2010). The farm settlements fetched a system, which was unfamiliar to native traditions and restricted their way of life. The entire settlements grew crops for exporting and produced little for consumption. However, the cash crops production increased, and the governments have not given much emphasis on native people and farmers that were interested and motivated for the farming and development (Korieh, 2010). Some scholars complained on the farm settlements, which were adopted from Israel. It obtained similarities with FELDA from Malaysia. In the central area, with solid selfcontrol, the government planned the farm settlements. The government has collectively carried the farmers, trained and assisted them with new seedlings to plant so as to overwhelm the farmers scattering. The farmers from villages were wishing to process and mill oil palm fruits in their own traditional way instead of carrying their fruits to mills. The cost of transport and transaction to pass the fruits that were harvested to mills would be very high, if to be compared with the Malaysian smallholder settlements (Kajisa et al., 1997). 


\subsection{Military/civilian rule policies; $1967-1999$}

The discovery of oil in Nigeria triggered civil war from 1967 to 1970, this war interrupted the boom of oil palm in Southeast of the country. As a result of the civil war, the exports of palm kernel and palm oil declined. In Cross River, this problem caused an economic decline of the state, which has the largest plantation in the region. The private estates entirely collapsed and became out of control with the exception of UAC (Schoneveld, 2014). There was a decrease in agriculture in 1970 as a result of petroleum boom. From 1974 to 1976, the palm kernels and palm oil trading died speedily (World Bank, 1978). Nigeria became under military regimes since from 1970 up to 1999. This led to different military policies on agriculture. Attempts were periodically made to improve agricultural sector but failed and food imports continued rising (Kajisa et al., 1997). In Nigeria, from 1986 to 1993, there was an implementation of a program called the Structural Adjustment Programme. This SAP devaluated Nigerian Naira by $80 \%$ and destroyed salary level in urban areas. The prices of agricultural produces inflated, the marketing board of palm oil has been abandoned due to the program hidden policy and agenda which spoiled the economy and declined the palm grove plantation (World Bank, 1989).

This programme has spoiled and deteriorated the Nigerian economy. Gradually, the prices of necessity goods such as food have increased and inflated to a level of decadence. Food prices became uncontrolled, it used to double time-to-time without any intervention from the government. The wives of retired officers owned and controlled big plantations of oil without following proper and legal way of ownership. The necessity goods prices increased in urban areas and became worst to control, this forced most of the people to engage in farming for survival. The earnings of the labour in the palm oil and rubber estates have augmented (Von Hellermann, 2007). SAP was introduced in Nigeria from 1986 to 1993, this program devaluated Nigerian Naira by $80 \%$, it spoiled the salary levels in urban areas, and led to an increase in prices of agricultural products. In 1986, Palm Oil Marketing Board was abandoned due to the implementation of Structural Adjustment and reduced the government participation and subsidy in the oil palm production (Schoneveld, 2014). In fact, the civil war in Nigeria caused the decline of agricultural sector, in particular palm oil.

\subsection{Civil government policies; 1999}

In 1999, due to the military regime transition to civilian rule, privatization policy was introduced from 1999 to 2007 to privatize resources under federal government administration. The civil government attached the program of alleviating poverty with the program of revitalizing agriculture. The government was trying to re-establish the supremacy of agriculture in the past before oil exploration (Anyanwu et al., 2011). Government policies on agricultural sector have heavily relied on partnership with Vegetable Oil Development Program (VODEP). Even though in 2002 and 2007 vegetable oil, manufacture enlarged, but lower than the goal. However, the key estate investment was an intensification of thirty-thousand hectares and an improvement of sixty-five percent of the mills, which were abandoned. Another goal was to expand the plantation to one million hectares to yield fifteen million fresh fruit bunches. However, VODEP was mostly regarded as private with little funding and support from the government. The government had imposed sanctions on fats and oils import, offered subsidy on fertilizer, and assured free tax for ten years on agriculture. The program faced some challenges of insufficient finance, ineffectiveness, using an old machine to process, lack of frequent power supply, and the road network was very poor (Anyanwu et al., 2011). 
Privatization policy among states has been temporarily rotated. In Cross River, the rubber plantation in 2003 has been sold (Schoneveld, 2014). In Cross River originally was agreed that the oil palm and cocoa plantations would not be sold and were provided for smallholders. This arrangement in 2010 was largely considered a failure to achieve the goals. Under the CARES program, smallholders with commercial orientation were offered 10-20 hectares by government for plantations. They were given good planting materials and free rent by the government. Due to mismanagement, they only planted 452 out of 4120 hectares. This program failed due to a lack of will and proper management, corruption, and inconsistency (Schoneveld, 2014). The Agricultural Transformation Agenda (ATA) came into being during the President Jonathan. This program presently is doing well for the industry to revive with the involvement of the private sector. The commercially oriented estates in 2012 were given enhanced planting materials for yielding twenty-one fresh fruit bunches per hectare in a year. Planting materials and funds would be given to farmers to plant (All Africa, 2012).

The Land Use Act of 1978 assigned the governors with lands and authority to allocate. The scheme provided the equality of land throughout the country. However, it provided too much power to state governors which caused interruption and the power has been frequently abused (Ayodele \& Eshalomi, 2010; El-Rufai, 2012). Now the government plans to make a new registration of lands and loans to farmers (The Citizen, 2013). The government tried to expand the production of oil palm to cater for the local consumption instead of importing palm oil from Malaysia, initially, its agriculturalists were trained in NIFOR (Osagie, 2013b). The food processing companies were importing palm oil; this became a threat to local production as well as the palm oil industry (POFON, 2013a). Other noodle companies were allowed to set up estates to overwhelm the palm oil scarcity. The Presco quickly enlarged and improved the production (Presco, 2013). In nutshell, the privatization policy failed to improve the palm oil production due to improper implementation.

\subsection{Findings from interviews}

In this study, open-ended interviews were used to uncover the unsustainable palm oil policies in Nigeria, due to improper implementation of the policies by different military and civilian government. Three participants were interviewed; they are professionally experts in economics and agriculture. The participants are all from Nigeria, they are educated by profession, and their ages are thirty to fifty-year oil. First participant holds a master's degree, and his position is a Chief Superintendent in agriculture, the second participant holds a degree in agriculture, and his position is a Senior Technical Officer in the Production and Processing Sector, both are permanent staff of Nigeria Institute of Oil Palm Research (NIFOR). The third participant holds a PhD. in economics, and a lecturer from Northwest University, Kano. They were chosen and interviewed based on their knowledge and profession in this field of study, and their willing to participate in this study.

Figure-1 shows the views of the three participants on unsustainable palm oil policies in Nigeria. The participant one said that palm oil policies in Nigeria became unsustainable due to politics; the majority of the farmers do not obtain government loans which is particularly provided for farmers. It is given to others that are not farmers and they know nothing about farming, and they do not even refund the loans given to them. The participant two explained that improper government palm oil policies as well as poor implantation led them became unsustainable, and the government do not pay much attention to the agriculture as a source of income. These problems led to the failure of most of palm oil policies in Nigeria. The participant three stated that palm oil policies 
in Nigeria are based on paper not really on the ground. The real farmers are small-scale farmers, and they occupied about the seventy percent $(70 \%)$ of agricultural sector. There are no actual policies, which encourage them, and transform them from substance farming to commercial farming. This is the reason why palm oil policies are unsustainable in Nigeria. All the three participants confirmed that palm oil policies in Nigeria are unsustainable and improperly implemented. These led to the failure of palm oil policies in Nigeria.

Figure -1: The participants on unsustainable Nigerian policies on Palm Oil

\begin{tabular}{|l|l|l|}
\hline $\begin{array}{l}\text { The policies on palm oil are } \\
\text { influential in such a way that, our } \\
\text { farmers are adopting it, currently } \\
\text { people are being given loans by } \\
\text { government to farm. While some } \\
\text { policies were politicised. Due to the } \\
\text { politics, most of the farmers do not } \\
\text { get the loans, they give it to some } \\
\text { people who are not farmers. And } \\
\text { they do not even refund the loans } \\
\text { because of politics, that's why the } \\
\text { policies failed. }\end{array}$ & $\begin{array}{l}\text { The policies are on paper not on } \\
\text { ground, the real farmers are small } \\
\text { scale farmers, they are about } \\
\text { seventy percent (70\%), no policies } \\
\text { that encourage them actually to } \\
\text { migrate from substance farming to } \\
\text { the commercial farming. }\end{array}$ \\
\hline $\begin{array}{l}\text { I don't think we have much policies } \\
\text { on oil palm production, actually } \\
\text { some of the problem we have, is } \\
\text { lack of good government policies } \\
\text { on palm oil. We didn't take it as } \\
\text { agricultural sector that can give } \\
\text { money, Government is not paying } \\
\text { much attention on that sector. }\end{array}$
\end{tabular}

\section{Conclusion}

This study briefly discoursed on palm oil historical background in Nigeria, facts about oil palm, facts about palm oil. It discussed on the unsustainable palm oil policies in Nigeria, starting from 1950s before independence up to present date. Different military and civilian governments adopted numerous palm oil policies in Nigeria. The policies were meant to diversify Nigerian economy especially agricultural sector, and particularly palm oil. Unfortunately, these policies became unsustainable and failed to improve palm oil sector as well as agricultural sector in general. There is a need for Nigeria to really learn from Malaysian palm oil policies transformation from primary based economy to industrialized economy. Nigeria has to increase its annual budget on agricultural sector at least ten percent (10\%) instead two percent $(2 \%)$ usually allocated by the government. This two percent is hardly to diversify Nigerian economy. Government and private sectors in Nigeria need to invest to improve agriculture particularly palm oil. The governments have to attract foreign investments through good policies due to the fertile land for oil palm plantation in Nigeria.

\section{Acknowledgement}

I would like to express my special gratitude and appreciation to this reputable journal of Research, my gratitude to its staff for good communication, and guidance for new researchers in this area of research. 


\section{Declaration of conflict of interest}

The author(s) declared no potential conflicts of interest(s) with respect to the research, authorship, and/or publication of this article.

\section{Funding}

The author(s) received no financial support for the research, authorship and/or publication of this article.

\section{References}

All Africa. (2012, August 31). Nigeria: FG targets the US 8 billion dollars from Palm Oil export. All Africa Vanguard.

Anthony, O.O. (2014). Economic survey of Oil Palm products' processing and marketing in Kogi State, Nigeria. The Journal of Sustainable Development, 13(1), 336-346. https://www.jstor.org/stable/26427287?seq=1\#metadata_info_tab_contents

Anyanwu, C., Amoo, B., Odey, L and Adebayo, O. (2011). An Assessment of the operations of the presidential initiatives on agriculture in Nigeria: 2001-2007. Occasional Paper, No. 40. https://www.cbn.gov.ng/Out/2013/RSD/CBN\%20Occasional\%20Paper\%2040\%20I nner.pdf

Ayodele, T., \& Eshalomi, M. O. (2010). African case study: Palm Oil and economic development in Nigeria and Ghana. recommendations for the world bank's 2010 Palm Oil strategy. Initiative for Public Policy Analysis (IPPA), Lagos Nigeria, 1-13 http://www.ippanigeria.org/articles/African\%20Case\%20Study $\% 20 \mathrm{Palm} \% 20 \mathrm{Oil} \% 2$ 0and\%20Economic\%20Development.pdf

Cohen, L., Manion, L. \& Morrison, K. (2007). Research method in education. Routledge.

Cress, J.W. (2012). Educational research: Planning, conducting, and evaluating quantitative and qualitative research, Fourth edition, PEARSON. University of Nebraska-Lincoln, U.S.

El-Rufai, N. (2012, December 20). Why Nigeria must revisit land reforms. Sahara Reporters. Green Palm. (2016). Palm oil facts. http://greenpalm.org/about-palm-oil/what-is-palm-oil

Green Palm. (2016). Where is palm oil grown? http://greenpalm.org/about-palm-oil/where-ispalm-oil-grown-2

Kajisa, K., Maredia, M., \& Boughton, B. (1997). Transformation versus stagnation in the Oil Palm industry: A comparison between Malaysia and Nigeria. Staff Paper, Department of Agricultural Economics, Michigan State University, East Lansing, Michigan.

Kilby, P. (1967). The Nigerian Palm Oil industry. Food Research Institute Studies, 7(2), 177201. Ageconsearch.umn.edu

Korieh, C. J. (2010). The land has changed: History, society and gender in colonial Eastern Nigeria. University of Calgary. https://prism.ucalgary.ca/handle/1880/48254

Malaysia-German Chamber of Commerce and Industry (MGCC). (2017). Palm Oil: Awareness and sustainability: A global perspective. EU-Malaysia Chamber of Commerce and Industry (EUMCCI), Kuala Lumpur, Malaysia.

Osagie, C. (2013b, May 23). FG, POFON battle to save Nigeria's oil palm plantations. This Day Live. https://books.google.com.my 
Palm Oil Research. (2014). Statistics. http://www.palmoilresearch.org/statistics.html

Palm Oil Value Chain Analysis in the Niger Delta (2011). Foundation for partnership initiatives in the Niger Delta (PIND), Abuja, Nigeria. http://www.fao.org

Plantation Owners Forum of Nigeria (POFON). (2013a). Communique of extraordinary meeting.

Presco. (2013). News from SIAT Nigeria Limited. Presco News. Presco-plc.com

Report on Palm Oil Value Chain Analysis in the Niger Delta. (2011). Foundation for Partnership Initiative in the Niger Delta (PIND) $1^{\text {st }}$ Floor St. James Building, 167 Ademola Adetokunbo Crescent, Wuse II, Abuja, Nigeria.

Schoneveld, G. C. (2014). The politics of the forest frontier: Negotiating between conservation, development, and indigenous rights in Cross River State, Nigeria. Land Use Policy, 38, 147-162. https://doi.org/10.1016/j.landusepol.2013.11.003

The Citizen. (2013, April 5). Government plans new land registration system. https://www.malaysia.gov.my

Udo, R. (1965). Sixty years of plantation agriculture in southern Nigeria: 1902-1962. Economic Geography, 41(4), 356-68. https://www.tandfonline.com/doi/abs/10.2307/141946?journalCode=recg20

Von Hellermann, P. (2007). Things fall apart? Management, environment and Taungya Farming in Edo State, Southern Nigeria. Africa, 77(3), 371-392. https://www.cambridge.org/core/journals/africa/article/abs/things-fall-apart1management-environment-and-taungya-farming-in-edo-state-southernnigeria/DC1DCD2BA47854D6306AB334CA7C98A3

Watson-Manheim, M.B., Chudubo, K., \& Crowston, K. (2002). Discontinuities and continuities: A new way to understand virtual work. Information, Technology, and People, 15(3), 191-209.

White, L. J., \& Oates, J. F. (1999). New data on the history of the plateau forest of Okomu, southern Nigeria: an insight into how human disturbance has shaped the African rain forest. Global Ecology and Biogeography, 8(5), 355-361. https://doi.org/10.1046/j.1365-2699.1999.00149.x

World Bank. (1978, May 24). Report and recommendation of the President to the Executive Directors on a proposed loan to Nigeria for a Nucleus Estate/ Smallholder Oil Palm Project in Rivers state. World Bank, Report No. P-2336-UNI.

World Bank. (1989, February 28). Staff Appraisal Report. Nigeria Tree Crops Project, Report No. 7429-UNI

World Bank. (2010). World Development Report 2010: Development and Climate Change. Washington DC.

World Bank. (n.d). PwC analysis. https://www.pwc.com/ng

Zhang, Y., \& Wildemuth, B.M. (2009). Qualitative analysis of content. Application of Social Research Methods to Questions in Information and Library Science, 1(2), 308-319. 